\title{
(2) Importance of preserving the resident microflora OPEN ACCESS of the skin to improve immunological response
}

\author{
Fabio Rinaldi, Giammaria Giuliani, Daniela Pinto
}

Human Microbiome Advanced Project (HMAP), Giuliani, Milan, Italy

Correspondence to Dr Daniela Pinto, Giuliani, Milano 20129, Italy; dpinto@giulianipharma.com

Accepted 20 April 2021 Published Online First 10 May 2021
As an interface with the outside environment, skin is colonized by a diverse collection of microorganisms-including bacteria, fungi, archaea, and viruses, protecting against invasion by more harmful or pathogenic organisms.

Skin acts also as an immunological barrier ${ }^{1}$ by educating the billions of $T$ cells inside the skin. This role is crucial in wounding and infection and for modulating the commensal microbiota that colonizes the skin. Indeed, by means of pattern recognition receptors, such as Toll-like receptors, mannose receptors, and the nucleotide-binding oligomerization domainlike receptor (NOD receptors), keratinocytes continuously sample the microbiota colonizing the skin surface. ${ }^{2}$

In this view, skin microbiota must be considered as one of the main factors influencing the response to infection since it has been recognized as a necessary element of immunity, being able to regulate the immune response of the host and also to maintain homeostasis. ${ }^{3}$

Hands represent a primary vector for infection transmission, including the so actual COVID-19 infection. The continuous presence of the virus forces almost all people to use Personal protective equipment (PPE) and disinfectant gels. They are fundamental, but they determine a series of skin alterations such as the disruption of the skin microbiome up to irritative dermatitis and alterations of the protective skin barrier. ${ }^{45}$ Because of the alteration of the skin barrier, there is an increase in the ability of microorganisms to spread through the skin and a decrease of the skin's immune response.

Hand microbiota is, among other body sites, one of the most subjected to a temporal variability $^{6}$ because of handwashing routine and hand sanitizer usage. These routines help us to protect against pathogens but what are they doing to hand's resident skin microbiota? Handwashing minimally impacts on microbiota healthiness but the widespread use of disinfectants, especially during COVID-19, has been reported to be detrimental to hand's microbiota homeostasis and antibacterial potential. ${ }^{4}$ This is the consequence of the reduction of species richness leading also to the alteration of skin structure (eg, barrier, hydrolipidic film) and functions such as immune response, colonization resistance (due to the presence of triclosan in hand sanitizers) but also the lowering of the production of antimicrobial peptides (dermcidin, LL-37) and exacerbation of inflammatory milieu. Indeed, the high content of alcohol in these products is responsible also for the dryness of the skin as for skin chronic inflammation.
Check for updates

(C) American Federation for Medical Research 2021. Re-use permitted under CC BY-NC. No commercial re-use. Published by BMJ.

To cite: Rinaldi $F$

Giuliani G, Pinto D.

$J$ Investig Med

2021;69:1386-1387.

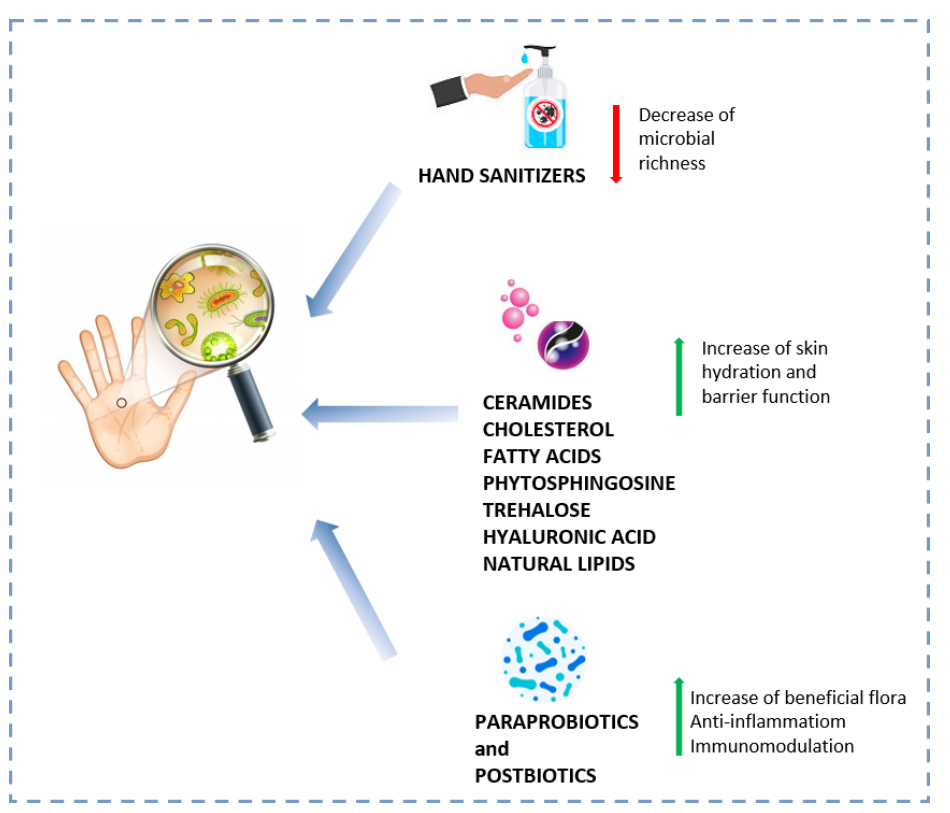

Figure 1 Schematic representation of the main factors affecting hand's microbiota. 
This evidence poses the need, now, more than ever, for specific topical formulations which can help to prevent and heal damages deriving from repeated hand sanitization procedure (figure 1).

The use of natural antimicrobial peptides and substances able to stimulate the natural defense system of the skin, for exampleprobiotics, could represent a very innovative as well as an effective approach. A new perspective is also that represented by postbiotics, active metabolites from probiotics with high specificity and effectiveness in both microbiota and immune defense modulation.

It is advisable, in our opinion, to adopt habits combining disinfectant gels and frequent washing to 'beneficial' topical formulation. As a result, also the immune response of the skin could be preserved.

Contributors FR conceptualized the study. DP and FR wrote the original draft. DP, FR and GG reviewed and edited the manuscript. FR and GG acquired the funding.

Funding The authors have not declared a specific grant for this research from any funding agency in the public, commercial or not-for-profit sectors.

Competing interests DP is employed by Giuliani. FR serves as a consultant for Giuliani. GG is on the board of directors of Giuliani.
Patient consent for publication Not required.

Provenance and peer review Not commissioned; internally peer reviewed.

Open access This is an open access article distributed in accordance with the Creative Commons Attribution Non Commercial (CC BY-NC 4.0) license, which permits others to distribute, remix, adapt, build upon this work noncommercially, and license their derivative works on different terms, provided the original work is properly cited, an indication of whether changes were made, and the use is non-commercial. See: http://creativecommons.org/ licenses/by-nc/4.0/.

\section{ORCID iD}

Daniela Pinto http://orcid.org/0000-0001-8107-106X

\section{REFERENCES}

1 Borkowski AW, Gallo RL. The coordinated response of the physical and antimicrobial peptide barriers of the skin. J Invest Dermatol 2011;131:285-7.

2 Grice EA, Segre JA. The skin microbiome. Nat Rev Microbiol 2011;9:244-53.

3 Eberl G. The microbiota, a necessary element of immunity. C R Biol 2018:341:281-3.

4 Yan Y, Chen H, Chen L, et al. Consensus of Chinese experts on protection of skin and mucous membrane barrier for health-care workers fighting against coronavirus disease 2019. Dermatol Ther 2020;33:e13310.

5 Lan J, Song Z, Miao X, et al. Skin damage among health care workers managing coronavirus disease-2019. J Am Acad Dermatol 2020;82:1215-6.

6 Edmonds-Wilson SL, Nurinova NI, Zapka CA, et al. Review of human hand microbiome research. J Dermatol Sci 2015;80:3-12. 